\title{
Citizen E-Participation Model in Resolving Covid-19 Pandemic in Indonesia
}

\author{
Ayuning Budiati ${ }^{*}$ Ipah Ema Jumiati ${ }^{2}$ \\ 1,2 Social and Political Faculty, Public Administration Department, University of Sultan Ageng Tirtayasa, Indonesia \\ *Corresponding Author: ayoekomara@gmail.com,emmaumar@gmail.com
}

\begin{abstract}
Indonesia is coping covid-19 pandemic since beginning of March 2020. Many policies and strategies that already conducted by the government to resolve this outbreak. The use of technology information is very important during this outbreak. 55\% people at Java Island use the internet and their gadget to gain information about its disease and how to cope and cure it, while people in Sumatera island uses 23\% of internet and their gadget to communicate and share information and even doing business, work from home and school from home. The rest is separate in other islands in Indonesia. However, there is no an eparticipation model that use in an integrated way to prevent this outbreak curve increase now. For example, people still come to market without hesitate even pandemic issues is still occurring. This research uses qualitative approach and descriptive qualitative method. Furthermore, this research uses library research and deep interview to gain data and information. This research argues that autonomous e-participation model can improve and prevent obstacles in coping this pandemic Covid-19. Autonomous e-participation such as using what's up and any social media that based on citizen's power: partnership, delegated power and citizen control can be an integrated model for decreasing the pandemic curve significantly.
\end{abstract}

Keywords: pandemic Covid-19, e-participation, Indonesia

\section{INTRODUCTION}

Indonesia is coping covid-19 pandemic since beginning of March 2020. Students have to study from home, people should work from their houses, and victims of this outbreak in Indonesia are hundreds. Many policies and strategies that already conducted by the government to resolve this outbreak. The use of technology information is very important during this outbreak. $55 \%$ people at Java Island use the internet and their gadget to gain information about its disease and how to cope and cure it, while people in Sumatera islands use $23 \%$ of internet and their gadget to communicate and share information and even doing business, work from home and school from home. The rest is separate in other islands in Indonesia. However, there is no an e-participation model that use in an integrated way to prevent this outbreak curve increase now. For example, people still come to market without hesitate even pandemic issues is still occurring. Based on that research background, the researchers will answer the question: How is citizen's e-participation in improving covid-19 resolution model in Indonesia?

This research' aims is to find a model in eparticipation of Indonesian in improving Covid-19 resolution and also to share it through seminars and journals in order the model will be used by Indonesian effectively.
This research' benefits are to broaden the researcher and Indonesian knowledge about e-participation in Indonesia especially in resolving Covid-19; and also by using this model effectively then Covid -19 outbreak impacts will be reduced. Moreover, other outbreak can use the model as a benchmark.

\section{LITERATURE REVIEW}

E-participation is generally defined as an area where ICTs are used in order to support citizens' engagement in defining the process and content of policy-making through deliberation and active decision-making initiatives. [1]

Whilst United Nation defines e-participation is as follow, e-participation "the process of engaging citizens through ICTs [Information and Communication Technologies] in policy and decision-making in order to make public administration participatory, inclusive, collaborative and deliberative for intrinsic and instrumental ends" [2]. That definition emphasizes the importance of citizen engagement and the use of ICT in participation for sustainable development and for facing the current global challenges such as climate change, poverty, disease like Covid-19 and the collaboration between governmental and all actors namely citizens, private sector, media, and academics. E- 
participation is a strategic factor to improve citizen participation in digital governance and to promote a more efficient society [2]

Despite of being frequently considered as an independent area of research, e-participation has a strong connection with e-democracy. Besides, methods and tools used to study e-participation are focused on the sociotechnical aspects of this phenomenon, while the methods and tools in the e-democracy domain are mainly used to assess democratic effects of ICTs.

E-Participation is about fostering people engagement through Information and Communications Technologies (ICTs) in all sectors- public, private, academics, media, society etc. E-Participation can be as a tool for engagement and strengthened collaboration between governments and citizens. Its objective is to improve access to information and public services as well as to promote participation in policy-making, both for the empowerment of individual citizens and the benefit of society as a whole. For example in improving social benefit at Covid 19 outbreak in leverage SMEs and economics as a whole by using ICT.

In the past twenty years, government and its stakeholders relation has evolved. There is a change perspective into using the internet. Usually it is called electronic government or digital government or even using social media. Whereas the internet become main tool including in collaboration and participation.

That new form of collaboration can create new ways to co-produce public policy and services. Indeed, in the digital age, many new information and communication technologies tools allow participation online, or eparticipation.

According to the e-participation researcher A. Macintosh, e-participation is: "ICT-supported participation in processes involved in government and governance. Processes may concern administration, service delivery, decision-making, and policy making" Implementing a successful eparticipation process means doing these 3 things online, namely:

1. Making the citizens aware on the topic presented in the forum

2. Enabling the discussion between citizens and all stakeholders to have good discussion

3. Empowering citizens to express their opinions on issues based on their preferences to have policy agenda in public policy process or service to be implemented by all stakeholders. [2]

Based on Corona Virus Task Force and Health Ministry, there are 135.123 people who got Corona Virus (August, 14th, 2020). Mortal number because of Corona is 6.021. Joko Widodo stated policy No 21 year 2020 about people health emergency due to Covid-19. For example, now Large Scale Limitation Area (PSBB) stated as Red Zone to cut the spread of Corona Virus. Meaning people cannot enter and go outside that area. This policy is effective to make the Corona Virus curve decrease.
Moreover, other precaution actions such as washing hands with soap regularly, social distancing, staying at home, using masker every time when urgently has to go outside. These policy and suggestions and health knowledge from the government can be disseminated through the internet or social media. Hence, e-participation occurs including in creating policy agenda, providing services for the citizens and people involvement in helping victims of Corona Virus, such as donating some fund for the victims, informing new hospital special for corona case (e.g. hotel atlit at Jakarta-, etc).

Autonomous participation is people engagement through the internet and using social media. Social media is media when socially people can get together, chatting, share information including picture, video and flyer.

Furthermore, autonomous e-participation such as using what's up and any social media that based on citizen's power: partnership, delegated power and citizen control can be an integrated model for decreasing the pandemic curve significantly.

At non participation step-therapy and manipulationis negative actions, therefore we will not discuss about it. Those are self-individual orientation and impact negative to the achievement of participation itself. For example, at stage manipulation and therapy, people give negative information (or false information) to influence people to do something, furthermore people is suggested to have therapy that influence to themselves only.

Furthermore, Coleman (2010) states kind of e-participation.

\section{What kind of e-participation?}

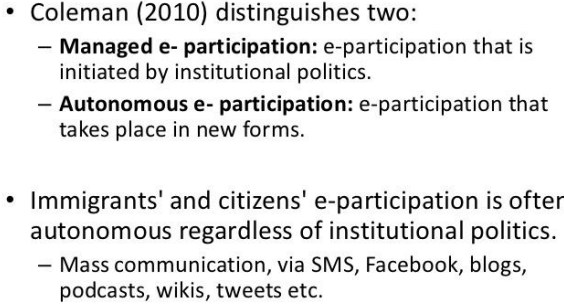

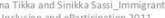

Figure 1. What kind of e-participation

Based on that theory, autonomous e-participation is not related to politics. Meaning, it does not related to certain government arms, society, organizations or even media. As long as using social media such as Facebook, blogs, what's App, Tweeter, Instagram, Line, podcast etc therefore it is autonomous e-participation.

Furthermore, Arnstein (1969) states in Tikka and Sassi (2011) that there is a ladder of participation namely: non participation, tokenism and citizen power. Whereas non participation consist of manipulation and therapy, while tokenism consists of informing, consultation, placation; and citizen power consists of partnership, delegated power and citizen control. 


\section{METHODS}

This research uses descriptive anaylysis methods and qualitative approach. The analysis uses library research. Data and information are gained from websites, newspapers, books and journals. Some local Indonesian websites the writers had from search engines during this year Corona Virus pandemic.

\section{RESULT AND DISCUSSION}

Based on statisca.com, Facebook users in Indonesia in 2020 are 2,4 billions, Youtube users 2 billions, WhatsApp and whatsApp Group users 1,6 billions, Instagram users 1 billions, and Twitter users 340 millions. These numbers show very important the use of technology and information and how very easy e-participation can be formed to resolve Covid-19 pandemic. Every day, Indonesian cannot live without their mobile phone and without checking their social media. Moreover, work from home and school from home make virtual class or virtual meeting is an obligation in New Normal era. Therefore, there is a need a model to be a portal of all those canals in communication virtually.

Moreover, according to the ladder of participation above then autonomous e-participation is included in the citizen power. Citizen power is where participation has three powers namely: citizen control, delegated power and partnership. Citizen power for example when people uses their social media for handling Covid-19 such Pikobar application at West Java Province.

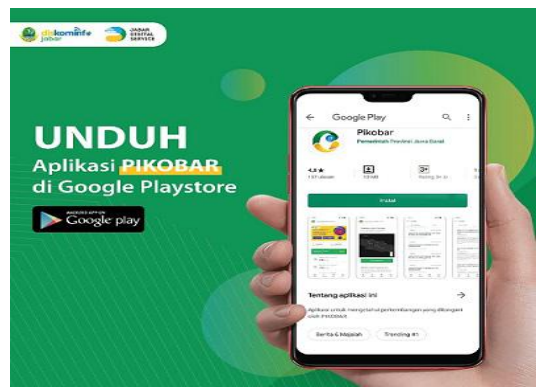

Figure 2 Aplikasi Pikobar

Moreover, delegated power when using social media where doing delegated power through the internet. Partnerships also using social media by government and other stakeholders for handling Covid-19 outbreak. For instance, halodoc application. Halodoc is an application where people can get health services including Covid-19 resolving problem through the internet or application. People can download the application in their mobile phone and contact their doctors to check their health, to get Swab test for Covid-19 virus.

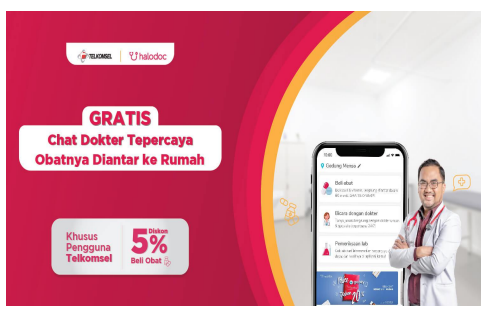

Figure 3 Aplikasi Halodoc

Application is a software at our mobile phone that has certain function based on our needs. For instance waze application is application in our mobile phone that we can download from play store or app store for helping the user guiding maps or places and also how to go there. Which way is shorter and safer. Therefore, people can gain benefit by using that application. There are applications that are used for Corona virus tracer (Desi,2020). For instance:

1. PeduliLindungi application. This application is developed by the Ministry of Communication and Information. PeduliLindungihas application is for tracking the movement of Covid-19 victims. This is very important due to have data how many people contagious by a victim. This application can be connected to mobile phone and other mobile phone operator to have the same visualized of Covid-19 movement of virus. PeduliLindungi is based on eparticipation by people who use this same application. People can share secure area data through this application when they go to certain places. Therefore, there is precautions actions.

The movement is work by using blue tooth active to record and compile data about the movement of the virus. The blue tooth can make other the same application user can exchange their anonymous id that automatically save into their own gadget. Then PeduliLindungi will identify people that ever been in Covid-19 victim or patients in monitored and or people in monitored. This application is Indonesian made.

2. 10 Rumah Aman. This application developed by President's staffs Office cooperation with the ministry of Information and Communication. This application uses Artificial Intelligent technology (AI) that is connected with map, data and social media platform. This application contains of Corona spread information, body temperature examining and checking areas regularly, and also online shop that sell daily needs.

3. Pikobar. This application is privilege for Wes Java people that is developed by west Java Province government. This application uses artificial intelligent system. This application gives information about Corona. For instance, it gives information about people that suspect of Corona virus, patient of Corona, moreover this application can detect 29 breath diseases not only Corona Virus disease.

4. FightCovid19

This application is developed by young Indonesian, Ahmad Alghozi Ramadhan. In this application people 
can gain information about: tracing people in monitored of Covid-19 and people without symptoms but have Covid-19 virus.

5. Tracetogether

This application is developed in Singapore. The function of this application is to identify people that contagious from Covid-19. It uses Bluetooth among mobile phones with maximum length two meters. The government will contact their citizen that has ever been contacted with the victim through their mobile phone.

4. Covid Symptom Tracker

This application is in England. The government will ask their citizen to report their condition. In one minute, people should report their condition every day.

5. Close Contact Detector

This application was developed in China by China Electronics Technology Group Corp (CETC). CETC uses data from related government's institution for tracing the movement of their citizens. Moreover, this application can indicate one person's health status, hence he or she can know get sick by Covid-19 or not.

6. AC19

Iran also has AC19 application to trace covid-19 virus. This application can states one person status within seconds. This application is also give recommendations to citizens whether they should hospitalized or selfquarantine.

7. Home Quarantine

This Home Quarantine application is from Poland. This application is to make sure that everyone stay at home. People should take a picture of themselves every day to assure government they are healthy. If only within 24 hours a citizen does not send their picture then the police will visit him or her.

Covid-19 patient in Indonesia is 12.776 people. Social media users in the world is 3.6 billion people, much more than SARS, bird flu, MERS and Pig Flu. WhatsApp and Instagram users in Indonesia increase up to $40 \%$ during corona outbreak. The reasons are many people communicate using whats up, whats up group and instagram during outbreak. Other countries in crisis of Corona - while the curve is on the top- the use of whats up is even more 51\%. According to Kantar stated by TechCrunch on Friday (27 $7^{\text {th }}$ of March 2020), at Spain the use of whats up is $76 \%$. Range of ages of whats up users are 18 up to 34 years old.

Furthermore, Facebook and Instagram users are increase significantly. For Instagram and Facebook increase $40 \%$ while WhatsApp increase $50 \%$ in March 2020. Facebook group increase more than $1.000 \%$ since February 2020. According to Facebook official stated by TechCrunch Kantar, Instagram and Facebook Live users are also double within a week. They are doing survey (since $14^{\text {th }}$ up to $24^{\text {th }}$ of March 2020) in twenty five thousands WhatsApp and Instagram users. Within a week, new posting at Instagram story increase $15 \%$ and their viewer increase $21 \%$.

The increase of WhatsApp and Instagram users is because in outbreak era many countries conduct.
Communication within family, relatives, colleague during lock down is conducted through WhatsApp dan Instagram.

The massive Indonesia's population and topography diversity has both positive and negative impacts on the ability of the government to deliver public services fairly and accessibly to every citizen. Difficulty to access services by the citizen can be caused by heavy traffic like in Jakarta and Surabaya (capital city of East Java), or due to the remote location of citizens who need to travel far to the service place.

Every Indonesian perhaps has to face difficulty in getting access to desired public services. The services vary from making and renewing ID cards, driving licenses, business licenses, paying taxes and bills (phone, water and electricity that have different places of payment) or just finding information relating to government's policies of some public issues, including about Covid-19 and actions to prevent and cure it. In fact, it is common practice in Indonesia that people should sacrifice their time or working time or even their daily income in order to get access to public services. They spend hours in traveling between their office or home to the administration offices, and hours in waiting for getting face to face with administration officers for handing in multiple of forms. If they are lucky enough, they can complete those services within one day; however, often they have to come back the next day, or two. It is a common practice that many of those who have lost patience will bribe officers to get faster service. Hence, it is difficult to get fair service for those who follow standard procedures.

By adopting e-participation, transparency will be occurs and bribing process can be eliminated. A renewal or proposed identification card processes currently allows people to bribe local government officers to have faster and easier access. For example, citizens can have two IDs and driving licenses (from Jakarta and Bandung cities) easily additionally by bribing process (Purbo, 2001). By using Internet to get an ID, it will reduce chances of bribery. Citizens visit the Internet and renewal process will be more efficient and effective. For example, government of city of Solo (Central Java) has implemented eparticipation where its citizens can get business license electronically (Kompas Cyber Media, 2003). Hence, unofficial fees or bribing processes can be eliminated, because those government's services can proceed without face-to-face contact. And also in gaining health service by using halodoc application can hindrance bribery and more efficient.

Using e-participation will give advantages such as efficiency, effectiveness, and transparency. As the United Nations (2001, p. 5) states, e-government (e-participation including in it) can create better service delivery to citizens and business, reducing corruption by increasing transparency and social control. In other words, eparticipation can improve government's capacity to serve their citizens.

E-participation in Indonesia focuses on how to integrate information and communication technology, which enhances the capacity of government to serve its citizens especially in this outbreak era. The government 
wished for a system that could integrate ideas and communication among the huge number of citizens across many different islands, each with different culture and characteristics. About $45 \%$ of local governments (provinces, districts and regencies) in Indonesia have already begun implementing e-government (including eparticipation). At the least, they have set up web sites (detiknet, 2003) that information about Covid-19 in it. How to do precaution actions such as social distancing, using masker when people outside, washing hands with soap or clean it with hand sanitizer.

\section{Proposing E-participation Model}

An autonomous e-participation model can improve and prevent obstacles in coping this pandemic Covid-19. Autonomous e-participation such as using what's up and any social media that based on citizen's power: partnership, delegated power and citizen control can be an integrated model for decreasing the pandemic curve significantly.

This model or portals are important as they can coordinate information from many sources, such as departments, agencies, and other government institutions. As Weill and Vitale (2001, p. 168) state, a portal is a gateway to the Internet or "a collection of useful links presented in an organized way from which users could get directions to other sites", thus a portal can reduce search costs, and possibly other transaction costs as well. Hence, if the citizens want to access any department or local government, then they can access through one Indonesian portal which saves time.

\section{CONCLUSION}

Indonesia's e-participation is still in the development stage, this is proved by the fact that only $9 \%$ of Indonesians can derive benefit from it. Autonomous e-participation as a portal for all social media, applications and internet device is very important in solving Covid-19 outbreak in Indonesia due to geographically reason (Indonesia consists of 13.677 island, 34 local government and 250 billion citizens).

\section{ACKNOWLEDGEMENTS}

Some suggestions regarding autonomous e-participation is putting free Wifi (wireless fidelity) in certain areas for more effective benefit of using the internet and application at citizen gadgets, rewards and punishment system for local government by central government in implementing this portal model, improvement in e-literacy by training for all Indonesian.

\section{REFERENCE}

[1] OECD (Organization for Economic Co-operation and Development). (2003), The E-Government Imperative, OECD Publications Services, Paris.

[2] United Nations. 2020. The Development Account Project on E-Participation. https://publicadministration.un.org/en/eparticipation.

(Date accessed 8th July 2020).

[3] Burhan, F.A. 2020. Penggunaan WhatsApp dan Instagram Melonjak Selama PandemiCorona, https://katadata.co.id/febrianaiskana/di gital/5e9a41f84eb85/penggunaan-whatsapp-daninstagram-melonjak-40-selama-pandemi-corona. (Date accessed 10th August 2020).

[4] Citizenlab.2017. The Frame Work That Make You Understand E-Partnerships Better. https:/www.citizenlab.co/blog/eparticipation/framework-will-make-you-understand-eparticipation/. (Date accessed 10th August 2020).

[5] Dzulfarih, A.N. 2020. "Bagaimana Media Sosial Pengaruhi Persepsi Publik terhadap Virus Corona?", (https://www.kompas.com/tren/read/2020/03/10/19113 7265/bagaimana-media-sosial-pengaruhi-persepsipublik-terhadap-virus-corona?page $=$ all, (Date accessed 8 August 2020).

[6] Gronlund, A. (2002), Electronic Government: Design, Applications and Management, Idea Group Publishing, Hershey.

[7] KDI School of Public Policy \& Management, OECD (Organization for Economic Cooperation \& Development), Korean Ministry of Planning \& Budget. (2003), International Seminar on Open Government, KDI School, OECD, Korean Ministry of Planning \& Budget, Korea.

[8] Komara, Rudiat.2007. Report: IT Governance in Indonesia. Jakarta: SPIMNAS LAN Jakarta

[9] Layne, K. \& Lee, J. (2001), "Developing Fully Functional E-participation: A Four Stage Model", Government Information Quarterly, No. 18, pp.122-136.

[10] Marche, S \& McNiven, J.D. (2003), "EGovernment and E-governance: The Future Isn't What It Used To Be", Canadian Journal of Administrative Science, Vol. 20, No. 1, pp. 74-86.

[11] Prins, J.E.J. (Eds). (2001), Designing Egovernment, On the Crossroads of Technological 
Innovation and Institutional Change, Kluwer Law International, Netherlands.

[12] The United Nations, Benchmarking E-government: A Global Perspective, http://unpan1.un.org/intradoc/groups/public/documents/ un/unpan003984.pdf, 2001, (Date accessed: 21 January 2003).

[13] The United Nations. (2003), World Public Sector Report 2003: E-government at the Crossroads, The United Nations, New York.

The World Bank, The E-government Handbook for Developing Countries, A Project of InfoDev and The Center for Democracy and Technology, http://www1.worldbank.org/publicsetor/egov/E-

gov\%20Handbook.pdf, 2003, (Date accessed: 10 November 2003).

[14] Weill, P \& Vitale, M.R. (2001), Place to Space, Migrating to eBusiness Models, Harvard Business School Press, Boston, Massachusetts.

[15] Weill dan Ross, (2004), IT Governance, How Top Peformers Manage IT Decision Rights for Superior Results, Harvard Business School Press, Massachusetts. 